Rzeczypospolitej, wygłoszonym przez dr. hab. Andrzeja Szymańskiego, prof. UO. Jako ostatni w tej sesji głos zabrał ks. kmdr dr Zbigniew Jaworski i przedstawił wystąpienie pt. Gwarancje wolności religijnej dla osób przebywajacych $w$ zakładach karnych $i$ w wojsku.

Sympozjum kończyła bardzo ciekawa, można by rzec ekumeniczna sesja, w której autorami referatów byli Naczelni Kapelani Więziennictwa RP. Zatytułowano ją: Raport o aktualnym stanie duszpasterstwa więziennego w Polsce wedtug Naczelnych Kapelanów Więziennictwa RP, a jej moderatorem był płk dr Jerzy Nikołajew. Kościół rzymskokatolicki reprezentował ks. dr Paweł Wojtas, Kościół Ewangelicko-Augsburski w RP ks. Piotr Janik, a Polski Autokefaliczny Kościół Prawosławny ks. dr Piotr Kosiński. Wszyscy duchowni zaprezentowali codzienne realia w jakich funkcjonuje duszpasterstwo więzienne w Polsce, charakteryzując przy tym stan personalny swoich ordynariatów. Po przedstawieniu referatów miała miejsce żywa dyskusja uczestników, a obrady zostały zamknięte przez prof. dr. hab. Tadeusza J. Zielińskiego, który podkreślił, że takie spotkania, jakie miały miejsce w Popowie, są wielce uzasadnione ze względu na „spotkanie” teorii z praktyką.

Dr Marek Bielecki

Wydział Zamiejscowy Prawa i Nauk o Społeczeństwie w Stalowej Woli Katolicki Uniwersytet Lubelski Jana Pawła II

\title{
Konferencja naukowa pt. Korelacje wolności religijnej indywidualnej i wspólnotowej, Jastrzębia Góra, 9-10 kwietnia 2015 r.
}

W dniach 9-10 kwietnia 2015 r. w Jastrzębiej Górze (Hotel Faleza) odbyła się konferencja naukowa nt. Korelacje wolności religijnej $i$ wspólnotowej. Organizatorami konferencji byli Wydział Prawa i Administracji Uniwersytetu Opolskiego oraz Polskie Towarzystwo Prawa Wyznaniowego.

W konferencji czynny udział wzięło 35 osób, reprezentujących 10 ośrodków naukowych: Uniwersytet Opolski, Katolicki Uniwersytet Lubelski Jana Pawła II, Uniwersytet Kardynała Stefana Wyszyńskiego, Uniwersytet Mikołaja Kopernika w Toruniu, Uniwersytet Rzeszowski, Uniwersytet Papieski Jana Pawła II w Krakowie, Chrześcijańską Akademię Teolo- 
giczną w Warszawie, Uniwersytet Przyrodniczo-Humanistyczny w Siedlcach, Wyższą Szkołę Finansów i Prawa w Bielsku-Białej, Wyższą Szkołę Stosunków Międzynarodowych i Komunikacji Społecznej w Chełmie.

W programie konferencji przewidziano cztery sesje: Zagadnienia ogólne, Zagadnienia prawnoporównawcze, Sfera wewnętrzna, Sfera publiczna.

Podczas pierwszej sesji, której przewodniczył prof. nadzw. dr hab. Dariusz Walencik (UO) wystąpiła trójka prelegentów: prof. zw. dr hab. Józef Krukowski (UKSW), prof. nadzw. dr hab. Piotr Steczkowski (UR) oraz prof. zw. dr hab. Artur Mezglewski (UO).

Zaprezentowali oni następujące wystąpienia: Godność osoby ludzkiejpodstawa poszanowania i ochrony wolności religijnej $w$ wymiarze indywidualnym $i$ wspólnotowym (J.K), Przynależność wyznaniowa a prawo Kościoła do określania jej warunków (P.S.), Wolność tworzenia kościołów $i$ innych zwiąków wyznaniowych oraz przynależności do nich (A.M.).

Sesji II przewodniczył prof. nadzw. dr hab. Mirosław Sitarz (KUL). $\mathrm{W}$ jej ramach swoje referaty przedstawili następujący prelegenci: dr Piotr Sadowski (UO), prof. dr hab. Wojciech Góralski (UKSW), dr Konrad Walczuk (UPH w Siedlcach), mgr lic. Michał Czelny (KUL).

Ich tematyka była następująca: Chrześcijanie a niechrześcijanie w cesarstwie rzymskim na przełomie $I V i V$ w. n.e. Analiza przypadku Hypatii i Rutiliusa Namatianusa (P.S.), Gwarancje wolności religijnej w Konwencji zawartej między Stolica Apostolska i Republika Zielonego Przylądka (W.G.), Indywidualne $i$ wspólnotowe wolności religijne $w$ stowackiej konstytucji (K.W.), Szczególne obowiąki nauczyciela religii w świetle wyroku Europejskiego Trybunału Praw Człowieka Martinez v. Hiszpania (M.Cz.).

Kolejnej - trzeciej - sesji przewodniczył prof. nadzw. dr hab. Andrzej Szymański (UO). W jej ramach swoje wystąpienia zaprezentowali: prof. zw. dr hab. Bartosz Rakoczy (UMK), dr Anna Tunia (KUL), dr Sławomir Hypś (KUL), dr Damian Szeleszczuk (KUL), dr Michał Zawiślak (KUL), dr Michał Chajda (Wyższa Szkoła Finansów i Prawa w Bielsku-Białej).

Tytuły przedstawionych przez nich referatów brzmiały: Życie $w$ instytucie zakonnym jako przejaw wolności indywidualnej $i$ wspólnotowej (B.R.), Obowiazek zachowania kanonicznej formy zawarcia małzeństwa - gwarancja czy limitacja wolności religijnej jednostki? (A.T.), Odpowiedzialność karna za przeszkadzanie w wykonywaniu aktu religijnego (S.H.), Ochrona jednostek $i$ grup wyznaniowych przed dyskryminacja z powodów religijnych $w$ polskim prawie karnym (D.Sz.), Wspótzależność $i$ współodpowiedzialność finansowa członków wspólnoty religijnej (M.Z.), Granice 
swobody testowania przez osoby duchowne i zakonne w kontekście ograniczeń tej wolności wynikających z prawa wewnętrznego związków wyznaniowych (M.Ch.).

W sesji IV, której przewodniczył prof. nadzw. dr hab. Piotr Stec (UO), wystąpili następujący prelegenci: prof. zw. dr hab. Tadeusz J. Zieliński (ChAT), dr Michał Skwarzyński (KUL), prof. nadzw. dr hab. Paweł Sobczyk (UO), prof. nadzw. dr hab. Andrzej Szymański (UO), dr Jerzy Nikołajew (WSSMiKS w Chełmie).

Przedstawione zostały przez nich następujące referaty: Korzystanie z klauzuli sumienia, jako realizacji wolności wspólnotowej czy/i indywidualnej (M.S.), Bezpieczeństwo państwa jako materialna przesłanka ograniczenia $w$ zakresie korzystania $z$ wolności religijnej indywidualnej $i$ wspólnotowej (P.S.), Budowa i odbudowa meczetów i muzutmańskich domów modlitwy w latach 1922-1939. Realizacja wolności indywidualnej czy wspólnotowej? (A.S.), Stałe struktury duszpasterstwa więziennego a indywidualna wolność religijna skazanych i tymczasowo aresztowanych (J.N.)

Poszczególne sesje wieńczyły dyskusje. Do tematów, które wywołały największe zainteresowanie należały:

- zasady określania warunków przynależności wyznaniowej,

- postulat wprowadzenia zasady samofinansowania się związków wyznaniowych,

- szczegółowe zasady konwojowania oraz dozorowania osób odbywających kary izolacyjne, w sytuacji gdy biorą one udział w praktykach religijnych,

- pragmatyka Departamentu Wyznań Religijnych oraz Mniejszości Narodowych i Etnicznych MAiC w przedmiocie rozpatrywania wniosków o zarejestrowanie związku wyznaniowego,

- sytuacja majątkowa zakonników - w tym zasadność ograniczeń osób zakonnych w zakresie rozrządzania swoim majątkiem na wypadek śmierci,

- status Kościoła katolickiego w Republice Zielonego Przylądka.

$\mathrm{Na}$ koniec warto dodać, że konferencja odbywała się w uroczym miejscu - na bałtyckim klifie, w miejscu, gdzie Rzeczpospolita Polska sięga najdalej na północ, tuż obok latarni morskiej na Przylądku Rozewie.

Ks. prof. dr hab. Artur Mezglewski Wydziat Prawa i Administracji Uniwersytet Opolski 